MAŁGORZATA DĄBROWICZ

ARTUR JAZDON

Biblioteka Uniwersytecka w Poznaniu

\title{
Założenia i realizacja polityki zarządzania zasobami w Bibliotece Uniwersyteckiej w Poznaniu w latach 1992-2014
}

\begin{abstract}
STRESzczenie. W artykule przedstawiono zmiany zachodzące w zarządzaniu zasobami Biblioteki Uniwersyteckiej w Poznaniu w latach 1992-2014. Na podstawie analizy wewnętrznych regulacji dotyczących polityki gromadzenia i związanych z nią zagadnień zaprezentowano jej ewolucję w ostatnim dwudziestoleciu. Omówiono także towarzyszące jej zmiany w organizacji pracy i strukturze oraz zarządzaniu Biblioteką.
\end{abstract}

SŁowA KLUCzowe: zarządzanie zasobami, polityka gromadzenia, gromadzenie zbiorów, źródła wpływów, selekcja, bibliotekarze dziedzinowi.

\section{Uwagi wstępne}

Od lat 80. XX wieku na grunt nauki, kultury, oświaty coraz powszechniej i z coraz większą świadomością przenoszone są założenia nauk ekonomicznych (w tym nauk o zarządzaniu), które w poprzednich dziesięcioleciach rezerwowane były głównie dla przemysłu, wytwórczości, usług itp. Jedno z owych podstawowych założeń można ująć skrótowo w następujący sposób: dla zarządzanych organizacji należy budować długoletnie strategie działań, w ich ramach - strategie funkcjonalne, odnoszące się do węższych obszarów działania, modyfikowane na poziomie zarządzania taktycznego, średniookresowego. Te natomiast należy rozpisywać i realizować na poziomie zarządzania operacyjnego, czyli upraszczając, np. w formie rocznych planów pracy.

Jednym z najważniejszych zadań każdej biblioteki jest troska o właściwe zarządzanie zasobami - w szerokim tego słowa znaczeniu. Należy bowiem założyć, że właściwie zbudowany zasób czy - mówiąc współcześnie - 
właściwa organizacja dostępu do niego będzie decydować o innych wyznacznikach funkcjonalności biblioteki: ustaleniu podstawowej dla niej grupy użytkowników oraz form, zakresu, częstotliwości i jakości świadczonych usług $\mathrm{w}$ ramach szeroko pojętego zaspokajania ich potrzeb.

Można stwierdzić, że w przypadku bibliotek uczelnianych ogólne, strategiczne, założenia kreowania kierunków rozwoju zasobu będą zapisane w statutach uczelni. Mogą być także powtórzone (zawarte) na przykład w preambule do ogólnego regulaminu biblioteki. Są to zapisy kierunkowe, o znaczeniu politycznym, ale niepozwalające na bezproblemową realizację działań praktycznych. $\mathrm{W}$ miarę upływu lat zmieniają się one nieznacznie, co jednak spowodowane jest decyzjami raczej niezależnymi od biblioteki, np. zmianą profilu uczelni, powstaniem lub likwidacją kierunków czy specjalizacji. Szczegółowe założenia polityki zarządzania zasobami winny być zapisane $\mathrm{w}$ dokumencie określającym przyjętą średniodystansową strategię funkcjonalną. Nowelizowane w odstępach kilkuletnich mają zapewniać realizację ogólnej strategii, a równocześnie stanowić punkt wyjścia do określania założeń krótkoterminowych, czyli planów rocznych. Z kolei wnioski płynące z bieżącej kontroli zarządczej $\mathrm{w}$ zakresie gromadzenia winny stanowić podstawę do ewentualnej modyfikacji założeń strategii funkcjonalnej.

Celem niniejszego artykułu jest przedstawienie, w jaki sposób na przestrzeni ostatnich 20 lat kształtowała się polityka zarządzania zasobami w Bibliotece Uniwersyteckiej w Poznaniu: co wpływało na formułowanie jej założeń, jak one się zmieniały i jak je zapisywano oraz jakie to miało konsekwencje dla organizacji pracy. Mamy świadomość, że w latach 1992-2014 w sposób ewolucyjny dokonaliśmy bardzo poważnych i daleko idących zmian, które obecnie warto podsumować. Powodem podjęcia tego tematu jest również fakt, że w roku 2015 zmienił się model finansowania wewnątrz uczelni, a także powstał projekt zmiany rozporządzenia kończącego epokę drukowanego egzemplarza obowiązkowego.

\section{Uwarunkowania zewnętrzne i wewnętrzne}

Pisząc o sformułowaniu w roku 1992 pierwszego dokumentu wewnętrznego, regulującego całościowo problematykę polityki gromadzenia, nie twierdzimy, że w poprzedzających go latach nie istniały ogólne założenia gromadzenia zbiorów i zasób powstawał w sposób przypadkowy. Jak ocenia Stanisław Kubiak, w okresie międzywojennym przepisy prawne, środki finansowe, zbyt szczupły personel i stosowane przestarzałe metody pracy stanowiły poważną przeszkodę do prowadzenia planowej polityki 
gromadzenia ${ }^{1}$. Tworzono zasób służący potrzebom dydaktycznym i badawczym rozbudowywanego Uniwersytetu. Bardzo ważny wyznacznik gromadzenia stanowiła wówczas polonizacja zbiorów², kształtowanych na podstawie dawnego zasobu Kaiser-Wilhelm-Bibliothek, rządzącego się w tym zakresie swoimi prawami ${ }^{3}$. Po 1945 roku stworzono odrębny oddział i dzięki temu rozwiązaniu - jak stwierdził Kubiak - „następował proces profilowania księgozbiorów z uwzględnieniem wszystkich czynników oddziaływujących bezpośrednio lub pośrednio na politykę gromadzenia zbiorów" ${ }^{\prime \prime}$. Nie była ona zdefiniowana w odrębnym dokumencie, ale wyznaczały ją następujące wytyczne: systematyczne kontynuowanie działów zapoczątkowanych $\mathrm{w}$ poprzednim okresie oraz bieżące potrzeby Uniwersytetu i środowiska poznańskiego. Dalej Kubiak podkreśla, że kontynuowano tradycyjne specjalizacje (problematyka niemcoznawcza i literatura regionalna) oraz że $\mathrm{w}$ ramach specjalizacji krajowej podjęto zadanie gromadzenia druków z zakresu skandynawistyki, nie osiągnięto jednak poważnych rezultatów ilościowych ${ }^{5}$.

Podstawowe kierunki organizacji zbiorów były, jak wspomniano, formułowane podczas określania ogólnych zadań biblioteki jako elementu uczelni. Stwierdzano bowiem zawsze, co pozostało aktualne do dziś, że biblioteka jest ważnym ogniwem wspomagającym prowadzone na uczelni badania i realizowaną $\mathrm{w}$ jej murach dydaktykę, a równocześnie ma charakter instytucji dostępnej publicznie. W początkowych latach odrodzenia Polski Uniwersytet, będąc jedyną uczelnią wyższą w Poznaniu, realizował szeroki wybór badań i zajęć dydaktycznych. Jego biblioteka, jako z założenia uniwersalna, gromadziła literaturę obejmującą całe spektrum wiedzy i udostępniała ją na określonych warunkach wszystkim zainteresowanym osobom. Sprzyjała temu również skromna - w stosunku do współczesnej - produkcja wydawnicza, pozwalająca bez większych problemów gromadzić wydawnictwa krajowe dzięki prawu do pozyskiwania najpierw regionalnego, a następnie ogólnopolskiego egzemplarza bibliotecznego. Takim założeniom w gromadzeniu sprzyjał też fakt, że nie był wykształcony system biblioteczny uczelni.

${ }^{1}$ S. Kubiak, Biblioteka Uniwersytetu im. Adama Mickiewicza w Poznaniu 1919-1966, Poznań 1967, s. 68.

2 Zob. M. Głowacka, Polonizacja księgozbioru Biblioteki Uniwersyteckiej w Poznaniu w latach 1919-1920, „Biblioteka” 2002, nr 6 (15), s. 87-96.

${ }^{3}$ Zob. Założenie Kaiser-Wilhelm-Bibliothek w Poznaniu w latach 1898-1902 przedstawione przez Zarzad Kaiser-Wilhelm-Bibliothek, Poznań 1904, przeł. R. Piejko, „Biblioteka” 2012, nr 6 (15), s. 17-56.

\footnotetext{
${ }^{4}$ S. Kubiak, Biblioteka..., s. 68.

${ }^{5}$ Ibidem, s. 68-69.
} 
Z biegiem lat sytuacja zmieniła się diametralnie. Z Uniwersytetu Poznańskiego wydzielały się bądź powstawały samodzielnie kolejne uczelnie państwowe, a od końca $X X$ wieku także niepubliczne, podejmujące badania i kształcenie zgodnie z przyjętym profilem. Tym samym Uniwersytet pomijał je w swym rozwoju. Jak zauważa Kubiak, już od lat 50. XX wieku zmniejszano w związku z tym zakres problemowy gromadzonych druków, rezygnując $\mathrm{w}$ zasadzie $\mathrm{z}$ dziedzin, które stawały się przedmiotem badań i dydaktyki powstających uczelni ${ }^{6}$. Ważne jest stwierdzenie „rezygnowano w zasadzie”, co w praktyce oznaczało nie całkowitą eliminację z gromadzenia piśmiennictwa $\mathrm{z}$ zakresu tych dziedzin, ale jedynie jego ograniczenie. Dalej autor określa, że ilość gromadzonych materiałów zależała głównie od możliwości finansowych Biblioteki, co oznaczało brak jakichkolwiek stałych założeń w tym względzie. Wskazuje natomiast na współpracę ze środowiskiem użytkowników w zakresie składania przez nich dezyderatów, choć - jak podkreśla - ostateczna decyzja należała zawsze do pracowników oddziału gromadzenia. W 1959 roku powołano Komisję Międzybiblioteczną, której centrala znajdowała się w Bibliotece Uniwersyteckiej. Jednym z jej czterech podstawowych zadań było właśnie ustalanie zakresu polityki gromadzenia zbiorów ${ }^{7}$. Mirosława Stempniewicz, charakteryzując pod tym względem lata 70. XX wieku, zauważa, że podkreślano konieczność planowania rozumianego jako kierowanie gospodarką zbiorami według z góry zatwierdzonego przez dyrekcję programu. Podjęcie celowych działań wymagało orientacji w aktualnym stanie zbiorów, konfrontowania go z obecnymi i przyszłymi zadaniami Biblioteki, tak aby harmonijnie powiązać $\mathrm{w}$ polityce gromadzenia tradycyjne specjalizacje ze współczesnymi, tworząc warunki dla perspektywicznego rozwoju nowych dyscyplin ${ }^{8}$. Wielokrotnie wspominany już Stanisław Kubiak, podsumowując w roku 1978 stan rzeczy, pisze, że po roku 1945 świadomie w gromadzeniu zwracano uwagę na specjalizację zbiorów. Stwierdza przy tym, że efekty w tym zakresie nadal nie są zadowalające i że problem ten nie został jeszcze (do tego czasu) rozwiązany zgodnie z potrzebami społecznymi ${ }^{9}$.

${ }^{6}$ Ibidem, s. 69.

${ }^{7}$ W. Wydra, Biblioteka Uniwersytecka w Poznaniu. Zarys dziejów, w: Dokumentacja działalności Biblioteki Głównej Uniwersytetu im. Adama Mickiewicza w Poznaniu 1919-1979, red. S. Kubiak, Poznań 1979, z. 1: Historia Biblioteki, s. 25.

${ }^{8}$ M. Stempniewicz, Gromadzenie i uzupełnianie zbiorów 1919-1979, w: Dokumentacja działalności Biblioteki Głównej Uniwersytetu im. Adama Mickiewicza w Poznaniu 1919-1979, red. S. Kubiak, Poznań 1979, z. 1: Historia Biblioteki, s. 98-99.

${ }_{9}$ Por. S. Kubiak, Rozwój bibliotekarstwa w Wielkopolsce po 1945 roku, w: Biblioteki Wielkopolski w stużbie nauki i kultury (1945-1977), red. S. Kubiak, Poznań 1978, s. 152. 
Trzeba zauważyć, że jednym z założeń obowiązujących przez te dziesięciolecia było dążenie do gromadzenia dużej ilości zbiorów, m.in. poprzez wieloegzemplarzowość $\mathrm{w}$ odniesieniu zarówno do wydawnictw zwartych, jak i do ciągów czasopism. O ile w latach 50. XX wieku wprowadzano do zbiorów rokrocznie około 20000 woluminów, o tyle w latach 70. - już do 80 000. Wówczas w Polsce więcej rokrocznie gromadziła tylko Biblioteka Narodowa, co podkreślano jako ważny wyznacznik sukcesu $\mathrm{BU}^{10}$.

W kolejnych latach $\mathrm{w}$ ramach uczelni powstawały biblioteki instytutowe, zakładowe, katedralne przekształcane od końca ubiegłego stulecia w biblioteki wydziałowe. Obecnie system biblioteczno-informacyjny UAM obejmuje Bibliotekę Uniwersytecką i 14 specjalistycznych bibliotek wydziałowych (lub dwuwydziałowych). Zlikwidowane zostały biblioteki mniejsze, a jako samodzielne funkcjonują jedynie biblioteki takich jednostek jak Ogród Botaniczny czy Obserwatorium Astronomiczne. Wyodrębnianie tych bibliotek, przypisywane im zadania nie mogły oczywiście pozostawać bez wpływu na praktykę gromadzenia w centrali.

Zmieniało się także oblicze krajowego ruchu wydawniczego, który przez długie lata oscylując rokrocznie $\mathrm{w}$ granicach kilkunastu tysięcy wzrósł z poziomu 10 000-11 000 tytułów w końcu lat 80. XX wieku do poziomu przekraczającego obecnie 33 000-34 000 tytułów wydawanych w postaci książek tradycyjnych. Pojawiły się ponadto książki elektroniczne, dokumenty dostępne w innej postaci, ogromnie rozwinął się rynek prasowy. Zniknął też praktycznie problem - nie licząc ograniczeń finansowych - z dostępem do literatury zagranicznej. Środowisko bibliotekarzy uświadamiało sobie, że polskie książnice muszą odstąpić od modelu biblioteki zasobowej na rzecz modelu biblioteki dostępowej, wprowadzić jako strategiczne działania związane z preselekcją a także selekcją zasobu. Potęgował te zjawiska ilościowy wzrost społeczności akademickiej, ale $\mathrm{w}$ jeszcze większym stopniu rozwój nauki, w tym kształtowanie się nowych dyscyplin, kierunków, prowadzenie badań na pograniczu nauk. Pojawiła się na koniec komputeryzacja bibliotek, wspomagająca realizację jednego z podstawowych założeń dotyczących kształtowania zasobów każdej biblioteki - świadomej współpracy w tym zakresie z innymi książnicami oraz dbałości o jasne określenie swej specjalizacji, wyróżnika na bibliotecznej mapie kraju.

10 A. Jazdon, Biblioteka Uniwersytecka w Poznaniu 1919-1994, „Kronika Miasta Poznania" 1994, nr 1/2, s. 334. 


\section{Wewnętrzne regulacje Biblioteki Uniwersyteckiej}

Pierwszy, niejako przygotowawczy dokument stanowiło zarządzenie z 1984 roku, regulujące zasady obiegu wpływów bibliotecznych [1] ${ }^{11}$. Jego celem było przyspieszenie realizacji zadań i zapewnienie najwartościowszym obiektom odpowiedniej kontroli ich przepływu wewnątrz Biblioteki. Trudno je jednak uznawać za znaczące dla określenia zasad polityki gromadzenia; o tym traktował bezpośrednio tylko jeden zapis, zobowiązujący Oddział Gromadzenia i Uzupełniania Zbiorów do stosowania właściwego doboru i racjonalnej selekcji. Nie określał on jednak, co przez te pojęcia należy rozumieć.

Pierwsza przedmiotowa regulacja ukazała się, jak wspominaliśmy, w roku 1992, w postaci zarządzenia wewnętrznego [4]. W preambule, jako uzasadnienie jego wprowadzenia, przywoływano omówione powyżej elementy, dodając, iż uwzględniono również oczekiwania społeczności akademickiej co do zadań realizowanych przez poszczególne ogniwa systemu biblioteczno-informacyjnego UAM. Dzięki temu, jak zakładano, winna nastąpić zmiana pełnionych przez nie funkcji, z przesunięciem obowiązku bieżącej obsługi potrzeb użytkowników na biblioteki sieci, a czyniąca Bibliotekę Uniwersytecką centralnym ośrodkiem informacji. Wyrażano również nadzieję, że taki podział zadań wpłynie na lepsze wykorzystanie gromadzonych zasobów, a także w sposób świadomy będzie służyć wykonaniu kolejnego kroku w kierunku specjalizacji gromadzenia bibliotek miasta. Wskazywano, że odtąd wpływająca na bieżąco czy selekcjonowana ze starego zasobu literatura techniczna ma być na mocy odrębnego porozumienia przekazywana Bibliotece Politechniki Poznańskiej, medyczna - Bibliotece Głównej Akademii Medycznej, a rolnicza Bibliotece Głównej Akademii Rolniczej. Tym samym wewnętrzny dokument nabierał szerszego - środowiskowego - znaczenia.

W dalszej części zapisów wstępnych stanowiono, że czasopisma specjalistyczne będą przekazywane bibliotekom sieci UAM na okres od pięciu do dziesięciu lat, po którym mogą być zwrócone do centrali celem ich wieczystego archiwizowania. Biblioteki sieci dokonujące selekcji swych zbiorów zostały zobowiązane do obligatoryjnego oferowania ich przed dalszym zagospodarowaniem Bibliotece Uniwersyteckiej w celu uzupełnienia ewentualnych braków. Miało to służyć realizacji zadania archiwizowania przynajmniej w jednym egzemplarzu wszystkich publikacji dokumentujących rozwój poszczególnych dyscyplin oraz szczególnie

${ }^{11}$ Oznaczenie w nawiasie kwadratowym odsyła do danej pozycji opisanej w załączniku. 
wkład uczonych i wydawnictw poznańskich czy szerzej wielkopolskich. Kierownicy tych bibliotek mieli odtąd także systematycznie przekazywać tzw. wykazy lektur, czyli spisy książek zalecanych studentom jako obowiązujące, po to aby w odpowiedniej liczbie egzemplarzy gromadzić je centralnie i udostępniać w księgozbiorze dydaktycznym. Wskazywało to zadanie postawione Bibliotece Uniwersyteckiej - wspieranie działań bibliotek sieci przez rozbudowę z własnych funduszy zasobów dydaktycznych, potrzebnych przede wszystkim na wydziałach. Miało to zmniejszyć dysonans pomiędzy oczekiwaniami studentów a finansowymi możliwościami ich zaspokajania przez te jednostki. Przewidywaną konsekwencją realizacji założonej polityki miało stać się zwiększenie zakresu jednoegzemplarzowości w gromadzeniu, a z kolei jej rezultatem - zwiększenie stopnia prezencyjności w udostępnianiu zbiorów. Na koniec podkreślano konieczność selekcji retrospektywnej zasobu i zapowiedziano wydanie stosownych zaleceń.

Dokument składał się z kilku rozdziałów, podzielonych na części. $\mathrm{W}$ rozdziale pierwszym stwierdzono, iż celem gromadzenia jest maksymalne - w miarę możliwości - zaspokajanie potrzeb badawczych oraz dydaktycznych pracowników i studentów UAM. Tym samym wskazywano, że właśnie oni stanowią podstawową grupę użytkowników, czego konsekwencjami były na przykład ograniczenia w dostępności do zasobu (kolejność obsługi, terminy wypożyczeń, uniemożliwienie bądź ograniczenie wypożyczeń zewnętrznych określonych materiałów) dla innych kategorii użytkowników. Formułując główne cele zarządzenia, sygnalizowano, że określa ono także podstawowe dla ich realizacji metody doboru, co rozumiano jako wskazanie: źródeł gromadzenia, liczby pozyskiwanych i gromadzonych tytułów oraz dodatkowych kryteriów wspomagających podejmowanie indywidualnych decyzji merytorycznych.

Rozdział drugi, zatytułowany Kierunki gromadzenia, określał, że gromadzone będą materiały odpowiadające dyscyplinom uprawianym na uczelni, a specjalizację nadal stanowią: niemcoznawstwo, skandynawistyka oraz literatura regionalna (dotycząca bądź powstała na terenie historycznej Wielkopolski $)^{12}$. Wykaz ten uzupełniły: literatura dotycząca północno-zachodnich ziem Polski (z racji pozostawania największą biblioteką naukową tych ziem) i literatura masońska. Ten ostatni element pojawiał się oficjalnie po raz pierwszy w tym dokumencie, ujawniając,

${ }^{12}$ Warto wskazać, że w cytowanym opracowaniu Dokumentacja działalności... zarówno Wiesław Wydra (s. 25), jak i Mirosława Stempniewicz (s. 104) wskazywali, że w latach poprzednich jako specjalizację traktowano również filologie krajów nadbałtyckich i południowej Słowiańszczyzny. Stempniewicz proponuje ponadto jako kolejne zakresy specjalizacji: literaturę anglosaska, wschodniosłowiańska, historię nauki. 
że w zasobach Biblioteki Uniwersyteckiej znajdują się - rozpoznawane wówczas - ogromne jej pokłady. Mimo iż nie funkcjonowało to w praktyce, wskazywano również, że BU w Poznaniu - świadoma wagi swej współpracy z Biblioteką Uniwersytecką w Warszawie, będącą I Centralną Biblioteką Nauk Społecznych - przyjmuje na siebie szczególny obowiązek gromadzenia literatury z tego zakresu.

W kolejnym, trzecim, rozdziale regulowano problematykę gromadzenia czasopism. Jako podstawową zasadę przyjęto, że wszystkie zagraniczne czasopisma naukowe kupowane będą centralnie z uczelnianych środków finansowych. Jednakże bibliotekom sieci dawano prawo zdublowania zasobu dzięki wymianie czy darom oraz pozyskiwania ze środków własnych innych tytułów niż wskazane na liście centralnej. W ten sposób, całkowicie wykorzystując pozostające do dyspozycji fundusze i minimalizując dublety, chciano zapewnić dostęp do jak największej liczby tytułów. Powtarzano, że wszystkie wzbudzające zainteresowanie czasopisma, w celu maksymalnego ułatwienia dostępu do nich, będą przekazywane bibliotekom sieci w depozyt na okres 5-10 lat, po którym mogą pozostawać tam nadal lub zostać zwrócone do centrali. Polskie czasopisma naukowe wpływające jako egzemplarze obowiązkowe pozostawały w Bibliotece Uniwersyteckiej, ale wszystkie ogniwa sieci miały prawo samodzielnego nabywania tych tytułów, w założeniu w jednym ciągu. Dopuszczano pozyskiwanie kolejnych ciągów tylko w sytuacji wymaganej potrzebami dydaktycznymi.

Czasopisma popularnonaukowe, społeczne, kulturalne, polityczne, wyznaniowe, sportowe itp. miały być gromadzone praktycznie jako wpływ obowiązkowy w Bibliotece Uniwersyteckiej, choć zakładano możliwość ich pozyskiwania przez wymianę czy dary w bibliotekach sieci. Jako zasadę ogólną przyjmowano, że żaden z tych tytułów nie powinien w systemie występować w liczbie większej niż dwa egzemplarze. W jednym ciągu i wyłącznie w centrali miały być gromadzone czasopisma o treści ogólnej, młodzieżowej, dziecięcej. Spośród czasopism lokalnych, regionalnych $\mathrm{w}$ zbiorach BU miały pozostawać wyłącznie te wydane na terenie północno-zachodniej Polski i Wielkopolski.

Obowiązek gromadzenia gazet codziennych ograniczono do Biblioteki Uniwersyteckiej i Dwuwydziałowej Biblioteki Nauk Społecznych. Nie oznaczało to, że pozostałe biblioteki nie mogły ich pozyskiwać dla swoich czytelników; zwolnione jednak były z zadania ich gromadzenia. Podkreślano, że przedmiotem zainteresowania gromadzenia są wyłącznie gazety o charakterze ogólnopolskim lub o - wskazanym powyżej - charakterze regionalnym. Tylko one mogły występować w zbiorach w dwóch egzemplarzach. Natomiast wszystkie mutacje gazet ogólnopolskich spoza regionu były odtąd eliminowane. 
Zapisy dotyczące podręczników (rozdział czwarty) okazały się dość proste do sprecyzowania przy założeniu współpracy wszystkich jednostek w sporządzaniu ich wykazów. Biblioteki sieci miały je gromadzić w liczbie uznanej za właściwą dla zaspokojenia potrzeb studentów. Biblioteka Uniwersytecka zakładała gromadzenie podręczników wykorzystywanych na wielu kierunkach studiów w 30 egzemplarzach, a specjalistycznych w 3-5 egzemplarzach. Realizację powyższych założeń miał zapewnić zakup, uzupełniany oczywiście egzemplarzami obowiązkowymi.

Kolejny rozdział (piąty), bardzo rozbudowany, poświęcony określeniu zasad gromadzenia książek naukowych, oddzielnie regulował kwestie związane $\mathrm{z}$ tzw. generaliami gromadzonymi $\mathrm{w}$ zależności od potrzeb we wszystkich bibliotekach systemu; publikacjami zagranicznymi i krajowymi, dysertacjami i wydawnictwami informacyjnymi. Podkreślano, że zakup książek w centrali cały czas był (i nadal jest) finansowany ze środków budżetowych, a w bibliotekach sieci - ze środków desygnowanych przez dziekanów, co dopuszczało stosowanie w nich indywidualnych rozwiązań. Jako zalecenia wskazano jedynie dążenie do minimalizowania liczby kupowanych książek, oparcie wpływu w centrali na egzemplarzach obowiązkowych oraz zasadę przekazywania materiałów specjalistycznych z tego źródła wpływów do bibliotek sieci. Obowiązek gromadzenia dysertacji doktorskich powstających na uczelni przypisywano Bibliotece Uniwersyteckiej, a prac magisterskich - na podstawie indywidualnych decyzji dziekanów bibliotekom systemu. Pozyskiwane na mikrofiszach dysertacje zagraniczne pozostawały w centrali, inne były przekazywane do jednostek sieci, które mogły także, w miarę swoich potrzeb, zabiegać o nie samodzielnie.

Założenia dotyczące wydawnictw informacyjnych łączono z rozdziałem dziewiątym zatytułowanym Gromadzenie nowoczesnych nośników informacji. Dopuszczano ich gromadzenie w wersji print, w zależności od charakteru (ogólne, specjalistyczne), w zainteresowanych nimi bibliotekach. Bazy danych na płytach CD i dyskietkach miały być gromadzone wyłącznie w Bibliotece Uniwersyteckiej oraz udostępniane w specjalnej czytelni lub, gdyby była taka możliwość, w wewnętrznej sieci uczelni. Zapisy te brzmią dziś dość archaicznie, ale taka była sytuacja w momencie przygotowywania dokumentu!

Krajową literaturę popularnonaukową miała gromadzić centrala dzięki wpływowi z egzemplarza obowiązkowego. Podobnie jak w przypadku publikacji zagranicznych nie przewidywano zakupu kolejnych egzemplarzy. Dopuszczano wyłącznie kupno wydawnictw polskich samodzielnie przez biblioteki sieci w sytuacji - jak to określono - „faktycznej niezbędności" i gromadzenie w systemie nie więcej niż dwóch egzemplarzy pozyskiwanych przez wymianę bądź dary. 
Zasób literatury pięknej (rozdział siódmy) w centrali postulowano budować na podstawie wpływu z egzemplarza obowiązkowego, z którego jednak zamierzano eliminować dalsze niezmienione wydania i masową literaturę sensacyjną. Zapoczątkowane już serie postanowiono kontynuować przez ich zakup w liczbie ciągów uznanych za konieczne. Zakładano celowy zakup przekładów na języki obce dzieł autorów polskich, a także dopuszczano uzupełnianie zbiorów $\mathrm{w}$ ramach wymiany czy darów. Zapisano, że literatura piękna będzie gromadzona również w bibliotekach wydziałów filologicznych i nauk społecznych, w wyborze i ilości dostosowanych do potrzeb dydaktycznych i badawczych. Podkreślano przy tym konieczność wieloegzemplarzowego pozyskiwania lektur.

Trzeba stwierdzić, że już na etapie tworzenia zapisów zdawano sobie sprawę z trudności precyzyjnego sformułowania zasad gromadzenia wydawnictw popularnonaukowych i literatury pięknej, przewidując $w$ tym zakresie problemy z podejmowaniem decyzji w codziennej pracy.

Ostatnią część dokumentu stanowiło wskazanie tzw. priorytetów, kryteriów porządkujących działania praktyczne. Pierwszym z nich był język publikacji - założono, że w centrali będzie gromadzona literatura w językach obcych: angielskim, francuskim, niemieckim, rosyjskim oraz skandynawskich. Chodziło o wyeliminowanie gromadzenia książek w językach, których nikła znajomość w społeczności użytkowników nie stwarzała szans na ich powszechne wykorzystywanie. We wszystkich jezykach europejskich, a z pozostałych - w tych, które stanowiły przedmiot kształcenia na uczelni, zakładano gromadzenie generaliów oraz literatury historycznej i geograficznej, przyjmując, że zagadnienia z tych obszarów wiedzy będą przedstawiane najwłaściwiej w językach narodowych. To ostatnie założenie przenoszono również na biblioteki wydziałowe: Wydziału Historycznego oraz Wydziału Nauk Geograficznych i Geologicznych. Natomiast biblioteki filologiczne miały gromadzić piśmiennictwo w językach wykładanych na poszczególnych kierunkach studiów. W pozostałych bibliotekach dopuszczano gromadzenie literatury w językach innych aniżeli pięć podstawowych (wymienionych wyżej), ale tylko na konkretne życzenie pracownika nauki.

Priorytet języka dominował nad priorytetem miejsca wydania i był decydujący $\mathrm{w}$ sytuacji wyboru piśmiennictwa zagranicznego. Przyjęto zasadę, że pierwszeństwo mają pozycje opublikowane w tych ośrodkach, dla których dany język jest językiem narodowym (używanym). Priorytet miejsca wydania został natomiast uznany za decydujący w gromadzeniu przez centralę pełnej produkcji wydawniczej Wielkopolski i przeważał w przypadku kolizji z nieprofilowym charakterem bądź treścią publikacji. 
Jeśli chodzi o publikacje regionalne, zakładano, że dla zapewnienia maksymalnej kompletności zasobu będą one pozyskiwane bez względu na datę wydania. Kryterium chronologiczne nie obowiązywało także w przypadku uzupełniania: serii, czasopism, wydawnictw wielotomowych oraz egzemplarzy wprowadzanych jako zastępcze za zagubione i zniszczone. Podobnie uznano, że nie obowiązuje ono w gromadzeniu pierwszych wydań dzieł literackich, książek z dedykacjami, bibliofilskich i innych wydań specjalnych. Niestety, nieprecyzyjny był ostatni zapis, mówiący o niewprowadzaniu publikacji starszych, uznanych za mało wartościowe naukowo. Zabrakło tu wyraźnego stwierdzenia, że nie gromadzi się literatury starszej niż np. dziesięcioletnia, co później zaczęto stosować domyślnie w podejmowaniu konkretnych decyzji.

Biorąc pod uwagę następne kryterium, ilościowe, przyjęto - poza wskazanymi już powyżej sytuacjami - zasadę jednoegzemplarzowości. Ostatnie kryterium określało gradację źródeł wpływów. Za podstawowe uznano egzemplarz obowiązkowy i zakup, w dalszej kolejności: wymianę, wymianę dubletów, dary i - jako ostateczność - depozyty. Zasadniczym źródłem wpływu dla czasopism była prenumerata, a dla zbiorów specjalnych - zakup.

Końcowe akapity zapowiadały przygotowanie odrębnego zarządzenia regulującego zasady gromadzenia zbiorów specjalnych, co faktycznie nastąpiło w niedługim czasie. Jako ważny element działania podnoszono w nich obowiązek okresowego (nie rzadziej niż raz na trzy lata) weryfikowania wypracowanych zasad. Zaproponowane założenia polityki gromadzenia zaczęły obowiązywać od 1 stycznia 1993 roku. Na ich podstawie opracowano i z tą samą datą wprowadzono w życie dokument Tryb i zasady przekazywania do innych bibliotek miasta Poznania wpływów z EO uznanych w BU za zbędne [5].

W 1996 roku, po czterech latach obowiązywania, przeprowadzono analizę dokumentu, w wyniku której przygotowano jego modyfikację [10]. Nowe zarządzenie zostało poprzedzone regulacjami: w roku 1994 dotyczącymi zasad i trybu prowadzenia selekcji księgozbioru głównego [6] oraz, w roku następnym, dotyczącymi zaprzestania gromadzenia nieprofilowych materiałów bibliotecznych [7].

Powodem przygotowania poprawek nie był brak przestrzeni magazynowej (ten problem można było rozwiązać, przesuwając materiały do magazynów składowych), lecz świadomość, że wielkość zasobu przekracza masę krytyczną i dalsze jego wzbogacanie na dotychczasowych zasadach nie tylko nie podnosi jego jakości, ale wręcz utrudnia jego prawidłowe wykorzystanie przez użytkowników. Dodatkowymi argumentami były: przygotowywanie do komputeryzacji i świadomość ogromu czekających 
zadań związanych z retrokonwersją zasobu. Uznano, że warto systemowo wyłączyć z niego nadmierną liczbę druków wieloegzemplarzowych i równocześnie, biorąc pod uwagę aktualną sytuację uczelni, zablokować dalszy wpływ materiałów zbędnych.

O drugiej przesłance była już mowa; wynikała ona ze zmian dokonujących się na mapie uczelni miasta. Brano pod uwagę też sformułowaną już w poprzednich latach przez Radosława Cybulskiego dyrektywę mówiącą o tzw. skanalizowaniu czytelnika ${ }^{13}$. Rozumieliśmy ją jako wyraźne wskazanie potencjalnej grupie odbiorców, że Biblioteka nie będzie gromadzić wszystkich materiałów, nie widząc sensu w połowicznej realizacji zadań związanych z kompletnością zasobu, co mogło skutkować niezadowoleniem czytelników z powodu niespełniania ich oczekiwań. Stwierdziliśmy, co podkreślono już poprzednio, że lepiej na przykład wpływy bieżące i starszą literaturę techniczną przekazywać do Biblioteki Politechniki, po to aby tam właśnie zainteresowani użytkownicy znajdowali jej pełen zasób.

Równocześnie byliśmy świadomi faktu, że realizowana od lat 60. XX wieku polityka wieloegzemplarzowego gromadzenia rodzimej produkcji wydawniczej, a także prowadzona na dużą skalę wymiana krajowa i zagraniczna owocowały nadmiernym przyrostem zbiorów. O ile mógł on być uzasadniony w przypadku literatury dydaktycznej (podręczniki, skrypty), o tyle nie był konieczny w przypadku pozostałych książek. Dodatkowo generował koszty - zarówno te bezpośrednie (oprawy, miejsce w magazynie), jak i pośrednie, związane m.in. z liczbą prac wykonywanych przy katalogowaniu (dla każdej książki sporządzano odrębną kartę katalogową). W szczytowych okresach wymianę prowadzono z prawie 1500 partnerami z całego świata, pozyskując nawet ponad 17000 woluminów, czemu odpowiadała zbliżona ilość materiału wysyłanego. I w tym wypadku należało uwzględnić: koszty nabycia materiału wysyłanego, realizację wysyłki (usługi pocztowe), wzrastającą rokrocznie ilość wpływającego materiału nieprofilowego i konieczność jego zagospodarowania. Pokazuje to nieproporcjonalny do efektów, zbędny wysiłek wkładany w realizację tych prac przez dość liczny zespół pracowniczy.

W dodatku prowadzona dostępnymi wówczas środkami (czyli bez zestawień generowanych automatycznie) analiza wskazywała, że wiele tytułów było wykorzystywanych $\mathrm{w}$ znikomym stopniu. Prace przygotowawcze do retrokonwersji unaoczniły, że z wprowadzonych do zbiorów

${ }^{13}$ Była ona sformułowana głównie w odniesieniu do organizacji księgarstwa, ale jako skrót myślowy chętnie odnosiliśmy ją także do bibliotek. Zob. R. Cybulski, Księgarstwo w społeczeństwie wspótczesnym, Warszawa 1978. 
pięciu czy dziesięciu egzemplarzy książki rodzimej produkcji zaczytane były $z$ reguły dwie, trzy pierwsze, według kolejności umieszczenia sygnatur na karcie bądź kart w katalogu alfabetycznym! Pozostałe były nieużywane, co zresztą decydowało o prowadzonej selekcji, polegającej na eliminowaniu egzemplarzy zaczytanych, a pozostawieniu tych w lepszym stanie.

Zakładając prowadzenie selekcji księgozbioru w ścisłej korelacji z założeniami polityki gromadzenia, zapisano, że nie selekcjonuje się druków wydanych przed 1945 rokiem. W przypadku stwierdzenia zbyt dużej i uznanej za zbędną liczby egzemplarzy takich druków decyzja o wycofaniu części z nich ze zbiorów miała być podejmowana po pozytywnej opinii Rady Bibliotecznej. Nakazywano obligatoryjnie pozostawiać w zbiorach po jednym egzemplarzu wszystkich pozycji, nawet gdy nie odpowiadały one merytorycznym założeniom polityki gromadzenia. W przypadku czasopism i gazet zdecydowano o możliwości pozostawienia dwóch ciągów, a prasy regionalnej lub innej o wyjątkowej wartości nawet trzech. Tyleż samo miało pozostawać egzemplarzy regionalnych wydawnictw zwartych oraz publikacji Wydawnictwa Naukowego UAM.

Realizację selekcji retrospektywnej zlecano przede wszystkim pracownikom odpowiedzialnym za klasyfikację piśmiennictwa, ze względu na znajomość zasobu z zakresu przypisanych im dziedzin. Równocześnie, jako obowiązkowe, zadanie to powierzano kierownikom oddziałów: opracowania zbiorów, katalogów oraz sekcji skontrum. Zakładano, że systematycznie pracują oni także nad zasobami starszymi i mają w tej kwestii dobre rozeznanie. Wszyscy pozostali pracownicy Biblioteki otrzymali możliwość (prawo) przekazywania wyznaczonym do tego zadania osobom swoich uwag czy sugestii. Miało to doprowadzić do sytuacji, w której praca nad selekcją zbiorów stawała się zadaniem szerokiego kręgu merytorycznie przygotowanych osób. Za całość działań i podejmowanie ostatecznych decyzji odpowiadał wskazany koordynator.

Jak wspomniano, w roku 1996 dokonano analizy i rewizji przyjętych wcześniej zasad gromadzenia. Dyskusje wykazały, że dokument z 1992 roku zasadniczo właściwie ujmował i regulował tę ważną problematykę. Nie były więc potrzebne daleko idące zmiany, jedynie pewne poprawki czy uzupełnienia, aby regulacje te stanowiły wciąż aktualną podstawę i wyznacznik do realizowania bieżących zadań w obszarach, których dotyczyły. Po zweryfikowaniu i uaktualnieniu części zapisów, z początkiem 1997 roku wprowadzono w życie dokument będący nowelizacją obowiązującej polityki gromadzenia [10]. Tego rodzaju okresową (cykliczną) nowelizację zasad gromadzenia wykonano jeszcze w latach: 2001, 2005, 2008 i wreszcie w roku 2013. W dalszej części artykułu spróbujemy prześledzić 
zmiany, korekty i uaktualnienia, co zobrazuje proces powstawania dokumentu w obecnym kształcie.

Podstawowe założenia i cele prowadzonej polityki gromadzenia zbiorów, jak do 2001 roku określano tę dziedzinę działalności bibliotecznej [14], od 2005 roku ujmując ją jako zarządzanie zbiorami [21], a od 2008 zasobami [23], nie zmieniały się w całym omawianym okresie. Wskazane korekty tytułów dokumentów wyrażają deklarację zróżnicowanego i zmieniającego się podejścia do problemu. Wynikały one z uświadomienia sobie, że gromadzenie zbiorów w dotychczasowej formule staje się niewystarczające i należy mówić o zarządzaniu zasobami ${ }^{14}$. Przez zarządzanie zasobami rozumiano nie tylko pozyskiwanie zasobów na własność, ale także organizowanie dostępu do nich. Uznawano też, iż poczynania w tym obszarze powinny być poprzedzone innymi działaniami wchodzącymi w zakres realizowanych zadań (lub uzupełnione o nie), takimi jak: świadoma preselekcja materiałów, ich selekcja, zastępowanie starszych wydań nowszymi, zmiana lokalizacji czy zasad ich udostępniania.

We wstępach do kolejnych dokumentów, wyjaśniających motywy wprowadzania regulacji, wskazywano także, poza stałymi - tylko częściowo przeformułowanymi - elementami uzasadnienia, konieczność prowadzenia preselekcji i dążenie do zwiększenia celowości gromadzenia zasobów, czyli powiązania w większym stopniu zasad i praktyki $\mathrm{w}$ tym zakresie z wnioskami płynącymi z analizy ich udostępniania [21]. Zwrócono również uwagę na świadome uwzględnianie szybkiego rozwoju technologii jako elementu wpływającego na ułatwianie dostępu do wiedzy [26].

W dokumencie z roku 2001 [14] poszerzono do pięciu wykaz bibliotek miasta, którym na mocy odrębnych porozumień przekazywano materiały wyselekcjonowane. Do wymienionych już trzech bibliotek uczelnianych dodano Publiczną Bibliotekę Pedagogiczną i Bibliotekę Raczyńskich. W 2005 roku dołączyła do nich także Biblioteka Główna Akademii Ekonomicznej, a w roku 2013 [26] było już dziewięciu odbiorców druków zbędnych BU (nowe biblioteki to: Biblioteka Uniwersytetu Artystycznego, Biblioteka AWF oraz Biblioteka Centrum Szkolenia Wojsk Lądowych). W trzech kolejnych dokumentach stwierdzano, że obdarowani nie mają prawa selekcjonowania przekazanego im materiału. Okazało się to jednak przeszkodą we wzajemnej współpracy, wobec czego w zarządzeniu z 2008 roku [23] zapis ten wycofano. Z identycznych powodów od 2001 roku wykreślono skandynawistykę jako zakres specjalizacji [14].

${ }^{14}$ Szerzej o tym problemie zob. A. Jazdon, O zarzadzaniu zbiorami, „Forum Książki" 1998, nr 2 (13), s. 8-9. 
W roku 1997 [10] wycofano zapis mówiący o tym, że ze względu na podział zadań pomiędzy poszczególne jednostki sieci centrala gromadzi literaturę z zakresu nauk filologicznych, historycznych i społeczno-prawnych. Piśmiennictwo z tych dziedzin nadal dominowało $w$ jej strukturze nabytków, zrezygnowano jednak z wyraźnego podkreślania tego faktu, aby nie było to odbierane jako ograniczenie zadań bibliotek sieci. W kolejnym zarządzeniu [14] do dyscyplin określanych dotąd jako niestanowiące przedmiotu szczególnego zainteresowania BU dołączyła teologia, co miało związek z powstaniem na UAM Wydziału Teologicznego.

Jeśli chodzi o gromadzenie czasopism, od roku 1997 [10] wszystkie biblioteki zobowiązywano do pozyskiwania ich w wersji tradycyjnej (o elektronicznej nie było jeszcze $w$ tym dokumencie mowy). W następnej regulacji [14] już zdecydowanie zaznaczono, że zapisy dotyczą $\mathrm{w}$ równym stopniu wersji drukowanej i elektronicznej, a w kolejnej [21] - że w przypadku występowania tytułu czasopisma w obu wersjach za podstawową uznaje się elektroniczną a drukowaną traktuje się wyłącznie jako uzupełniającą. W ostatnim dokumencie [26] zapisano jednoznacznie, że nie wprowadza się do zbiorów tytułów czasopism dostępnych online, a gdyby ich redakcje tworzyły i utrzymywały archiwa z lat poprzednich, powinno się wycofywać zasoby drukowane tych czasopism ze zbiorów. Odzwierciedlało to zasadniczą zmianę w gromadzeniu, mającą swoje konsekwencje także w zakresie opracowania i udostępniania.

Na mocy zarządzenia z roku 1997 [10] zaprzestawano też gromadzenia czasopism reklamowo-informacyjnych, handlowych, popularnych, rozrywkowych, młodzieżowych, paranaukowych i innych o niskiej wartości merytorycznej. Decyzja ta była wynikiem zalewu rynku prasowego takimi właśnie tytułami. Od roku 2001 [14] wpływające egzemplarze obowiązkowe czasopism młodzieżowych i dziecięcych przekazywane były do Biblioteki Raczyńskich, a od 2013 [26] czasopisma studenckie kierowano do właściwych bibliotek wydziałowych. Przestano również gromadzić dzienniki z terenu północno-zachodniej Polski [10], ograniczono się do szeroko rozumianego obszaru Wielkopolski. Wprowadzono wówczas zapis, że dzienniki zagraniczne będą pozyskiwane i udostępniane, poza szczególnymi wypadkami, wyłącznie w bibliotekach sieci. Nie oznaczało to obowiązku ich gromadzenia! Jeśli którykolwiek z nich miał być gromadzony, to tylko w centrali i na nowoczesnych nośnikach.

Liczba gromadzonych podręczników została pierwotnie [10] zwiększona odpowiednio do 50 (podręczniki ogólne) i 10 (specjalistyczne), co było odpowiedzią na wzrost liczby studentów. Przewidywany jej spadek i względy finansowe nakazały w 2013 roku [26] wrócić do poprzednich zapisów (odpowiednio 30 i 10 egzemplarzy). Dążąc do stałej obecności 
podręczników w zasobach i dając studentom możliwość każdorazowego skorzystania z nich na miejscu, w kolejnych regulacjach [od 10] zapisywano, że najpierw trzy, a później jeden egzemplarz każdego tytułu ma zostać oznaczony jako niewypożyczany na zewnątrz (egzemplarz prezencyjny). W związku z dużą liczbą skryptów, wydawanych przez różnego typu uczelnie niepubliczne i kierowanych do swoich studentów, zaprzestano ich gromadzenia [14]. Wyjątek czyniono dla tytułów polecanych przez prowadzących zajęcia dydaktyczne i wskazanych przez nich jako warte zatrzymania [26]. Zapisano również, że centrala będzie gromadzić podręczniki dla szkół podstawowych i średnich, natomiast specjalistyczne (do nauki przedmiotów zawodowych) będzie przekazywać szkołom lub instytucjom kształcenia zawodowego [10]. W kolejnym dokumencie [14] zapis ten zmieniono, podejmując decyzję, że podręczniki dla szkół podstawowych, gimnazjalnych i średnich będą przekazywane do Publicznej Biblioteki Pedagogicznej. Na wniosek bibliotek sieci ten zapis doprecyzowano i od 2008 roku [23] podręczniki są najpierw oferowane bibliotekom UAM, a dopiero w sytuacji braku zainteresowania $\mathrm{z}$ ich strony przekazywane do Publicznej Biblioteki Pedagogicznej.

Uszczegółowiane były też zasady dotyczące publikacji naukowych. Zgodnie z dokumentem z roku 1997 [10] zaprzestawano zasadniczo gromadzenia nadbitek, domyślnie - z wyjątkiem tych posiadających cechy specjalne, np. autografy autorskie. Zastrzeżono, że mikroformy zbierane będą tylko w przypadku zastępowania lub uzupełniania zbiorów wartościowych, niedostępnych na rynku księgarskim w postaci tradycyjnej. Zasadę tę rozszerzono następnie na materiały na nośnikach elektronicznych [21]. W tym zarządzeniu określano również, które dokumenty rządowe i Unii Europejskiej będą zbierane, dając prawo do tego wszystkim bibliotekom systemu zgodnie z ich potrzebami. W 2013 roku [26] pojawił się zapis, że Biblioteka Uniwersytecka kupuje zagraniczne opracowania monograficzne wskazane przez bibliotekarzy dziedzinowych, pracowników nauki oraz przez użytkowników w ramach wprowadzonej usługi „Zaproponuj kupno książki”. Był to zapis ważny ze względu na zasugerowanie zalecanego trybu podejmowania decyzji.

Generalne założenia gromadzenia literatury pięknej nie zmieniły się zasadniczo, mimo - przypomnijmy - świadomości problemów z precyzyjnym ich sformułowaniem. Jednakże $w$ zapisach ostatniej regulacji z roku 2013 [26] widać modyfikacje. W 2005 roku [21] sprecyzowano zasady $\mathrm{w}$ kwestii podejmowania decyzji dotyczących gromadzenia (bądź nie) wydań poezji. Praktyka dnia codziennego pokazywała wpływ znacznej ich liczby, o bardzo zróżnicowanym poziomie, niełatwych do obiektywnej oceny przez bibliotekarzy. Mieliśmy świadomość, że większość 
z nich, po włączeniu do zbioru głównego, staje się dla czytelników praktycznie niewidoczna. Dlatego od roku 2005 [21] w zbiorach BU pozostawać miały tylko: dzieła zbiorowe, zebrane, wysokiej klasy artystycznej utwory autorskie, wydania autorów wielkopolskich oraz tekstów nagradzanych w konkursach poetyckich. Pozostałe przekazywano do Biblioteki Wydziału Filologii Polskiej i Klasycznej.

Dokument z roku 2013 [26] nieznacznie różni się pod tym względem od poprzednich. Już w pierwszym, poświęconym tym zagadnieniom punkcie podkreślano, że Biblioteka Uniwersytecka gromadzi literaturę piękną w wyborze. Ograniczenie to stało się konieczne w sytuacji pojawiania się ogromnej liczby propozycji wydawniczych na różnym poziomie. Zgodnie z przyjętymi w zarządzeniu kryteriami doboru utworów prozatorskich Biblioteka ma gromadzić je w jednym egzemplarzu (poza wydawnictwami krytycznymi, lekturami, utworami nagradzanymi światowymi bądź polskimi nagrodami literackimi), unikając gromadzenia literatury obcojęzycznej, z wyjątkiem klasyki światowej i tłumaczeń autorów polskich. Te do pewnego stopnia uszczegółowione, ale wciąż dość ogólne wytyczne są niezbędne do podejmowania racjonalnych, a nie przypadkowych decyzji przez członków zespołu ds. selekcji bieżącej literatury pięknej, o którym mowa w dalszej części artykułu.

W dokumencie z 2008 roku [23] zapisywano, że zapoczątkowuje się gromadzenie komiksów jako źródeł pierwotnych do prowadzenia badań naukowych i dydaktyki oraz opracowań na ich temat. Szczegółowo zasady tworzenia kolekcji opisano w oddzielnym dokumencie [24]. Wynikało to z podjętej wcześniej decyzji o systematycznym tworzeniu kolekcji komiksów ze względu na społeczną wagę zjawiska i zainteresowanie nimi przedstawicieli wielu dyscyplin. Stanowiło to z jednej strony wypełnienie luki dostrzeżonej w zasobach miejscowych Biblioteki Uniwersyteckiej, z drugiej - inaczej sytuowało ją w środowisku lokalnym. Biorąc pod uwagę fakt, że komiksy wzbudzały zainteresowanie bardzo zróżnicowanych środowisk, przez ich gromadzenie i udostępnianie Biblioteka otwierała się na inne niż podstawowe grupy użytkowników. Ich zbieranie potraktowano jako specjalizację, choć nie zdecydowano się tego tak nazwać w części wstępnej, wskazującej obowiązujące kierunki specjalizacji. Ostatnia regulacja [26] informuje, że Biblioteka przyjęła na siebie nowy obowiązek, za jaki należy uznać gromadzenie liberatury - bardzo interesującego zjawiska literackiego, artystycznego i edytorskiego.

Co do tzw. kryteriów pomocniczych wymienianych na końcu każdego z dokumentów założoną w stosunku do poprzednich zmianą było umieszczenie w regulacji z 2013 roku [26] na pierwszym miejscu źródeł 
nabycia. Za celowe źródła wpływów uznano kupno i egzemplarz obowiązkowy, pozostałe potraktowano wyłącznie jako uzupełniające, co pokazuje przyjęty priorytet. Teoretycznie niezauważalna, ale też wprowadzona nie bez przyczyny, była zmiana dotycząca kryterium językowego, gdzie wskazano jako języki podstawowe (obce) angielski i niemiecki, rezygnując z równorzędności z nimi francuskiego i rosyjskiego.

W dokumencie z roku 2005 [21] dodano - i powtórzono w kolejnych osobny, krótki rozdział opisujący założenia polityki zagospodarowania druków zbędnych, wskazując ustaloną kolejność ich proponowania innym jednostkom. Na czele listy umieszczono biblioteki wydziałowe, dalej plasują się biblioteki, z którymi w miarę upływu lat podpisywano stosowne porozumienia, a następnie kolejno - inne (naukowe, szkolne) biblioteki miasta, regionu itd. Przez zamieszczoną na stronie internetowej BU tzw. ofertę dubletów docieramy również do innych zainteresowanych bibliotek czy instytucji na terenie kraju i poza jego granicami [26].

Celowo z niniejszej analizy wyłączono problematykę gromadzenia zbiorów specjalnych. Wymaga ona odrębnego potraktowania, ale warto powiedzieć, że w roku 1989 po raz pierwszy opracowano Zasady i profil gromadzenia zbiorów specjalnych w Bibliotece Uniwersyteckiej w Poznaniu oraz tryb ich opracowania [2], pogłębione i uszczegółowione w dokumencie z 1997 roku zatytułowanym Zasady i profil gromadzenia zbiorów specjalnych w Bibliotece Uniwersyteckiej w Poznaniu [7]. Omówione uprzednio kolejne dokumenty dotyczące polityki gromadzenia odsyłały właśnie do tych zapisów. Nie wracano do korekty zarządzenia z 1997 roku, ponieważ gromadzenie zbiorów specjalnych zawsze uważano za niezwykle ważne, a jednocześnie - ze względu na ich charakter, zabytkowość, unikatowość, specyficzne prawa rynku - niemożliwe do regulacji tak szczegółowych jak w przypadku materiałów współczesnych. W ostatniej regulacji [26] podkreślono więc tylko te najważniejsze założenia, zgodnie z którymi szczególną wagę przywiązuje się do pozyskiwania zbiorów zabytkowych, powstałych na terenie Wielkopolski do roku 1953 oraz związanych z nią tematyka, miejscem powstania, osobą twórcy, proweniencjami. Widać tu wyraźne nachylenie ku tworzeniu kolekcji regionalnej i przesunięcie cezury czasowej.

W każdej z dotychczasowych regulacji w uwagach końcowych nakładano obowiązek ponownej ich analizy po upływie trzech lat, a także zalecano, aby wszystkie występujące $\mathrm{w}$ praktyce, a niewyszczególnione przypadki, rozstrzygać z zachowaniem ścisłej zasady specjalizacji zbiorów, a od 2013 roku - jak zaznaczano w dokumencie [26] - również we współpracy ze środowiskiem użytkowników. 
Przedstawiona analiza kolejnych regulacji zarządzania zasobami z ostatnich 20 lat wykazuje niezbicie, jaką koniecznością jest sprecyzowanie $\mathrm{w}$ formie dokumentu szczegółowej i podstawowej strategii funkcjonalnej, wpływającej też na inne sfery działania Biblioteki, w tym udostępnianie. Jak wynika z powyższego, nie można tych dwóch zakresów rozpatrywać rozłącznie. Warto zaznaczyć, że właściwie przygotowany i dobrze przemyślany dokument początkowy może być punktem wyjścia do działania przez wiele lat. Taki stan rzeczy uważamy za optymalny, wychodząc z założenia, że strategia szczegółowa musi stanowić układ względnie stałych zasad. Podstawowe ustalenia zostały zachowane, były natomiast doprecyzowywane i uzupełniane $\mathrm{w}$ toku działań praktycznych i wynikających z nich doświadczeń, z uwzględnianiem zmieniających się warunków otoczenia oraz rozpoznawanych oczekiwań i potrzeb użytkowników. Efektem opracowywania kolejnych wersji tego dokumentu było również doprecyzowywanie innych, z nim powiązanych, w tym dotyczących zwłaszcza selekcji zbiorów [np. 19 i 27]. Selekcja prospektywna była - i jest - prowadzona na bieżąco, na podstawie założeń polityki tworzenia zasobu, natomiast zmiany $\mathrm{w}$ tym zakresie rzutowały też na założenia selekcji retrospektywnej, zarówno w ujęciu merytorycznym, jak i w zakresie organizacji tego zadania.

\section{Wprowadzone rozwiązania organizacyjne}

Podczas analizy dokumentów dotyczących zasad zarządzania zasobami wskazywaliśmy sporadycznie na pewne powiązane z nimi i często z nich wynikające elementy rozwiązań organizacyjnych, których wprowadzenie w życie miało przyczynić się do jak najwłaściwszej realizacji przyjętych założeń. Przez całe dwudziestolecie bowiem staliśmy na stanowisku, że nie wystarczy sprecyzowanie zapisów teoretycznych, ale rolą kierownictwa Biblioteki jest proponowanie i wdrażanie rozwiązań usprawniających działania praktyczne.

Pierwsze z przywoływanych zmian nazwać można politycznymi, a dotyczyły one wyłonienia spośród pracowników BU Komisji Selekcji i Doboru oraz - nieco później - Zespołu Bibliotekarzy Dziedzinowych, które odtąd stały się merytorycznym zapleczem, wsparciem Oddziału Gromadzenia i Uzupełniania Zbiorów. Tym samym zdjęto z tego oddziału ciężar samodzielnego podejmowania decyzji, doprowadzając do sytuacji, w której inni pracownicy uzyskali znaczny wpływ na kształtowanie zasobu. Oddział Gromadzenia nadal jednak pozostaje niezwykle ważną jednostka, w większym stopniu odpowiedzialną za przygotowanie 
materiałów i tworzenie sytuacji wspomagających podejmowanie decyzji, zorganizowanie tego procesu i koordynowanie nim, a następnie sprawne i najkorzystniejsze z punktu widzenia uczelni zrealizowanie zamówień.

Zasadnicze procesy decyzyjne zostały natomiast przesunięte głównie na dwa wymienione zespoły ${ }^{15}$. Zadaniem ich członków, rekrutujących się z grona pracowników większości oddziałów Biblioteki, jest uczestnictwo w cotygodniowych spotkaniach roboczych, codzienna współpraca z kierownikiem Oddziału Gromadzenia, sterującego ich pracami, a także współpraca z użytkownikami. Szczególnie bibliotekarze dziedzinowi predestynowani są do tego, aby w większym stopniu próbować rozpoznawać potrzeby użytkowników i uwzględniać płynące od nich sygnały ${ }^{16}$.

W skład działającej od 2005 roku [od 21] Komisji Selekcji i Doboru wchodzą kierownicy i pracownicy w zasadzie wszystkich komórek organizacyjnych Biblioteki. Co ważne, pracują w niej osoby z Oddziału Udostępniania oraz z innych oddziałów mających kontakty z różnymi grupami użytkowników (Oddział Informacji i Transferu Wiedzy, Oddział Zbiorów Specjalnych), dzięki czemu w jak największym stopniu możliwe jest zbieranie i uwzględnianie uwag użytkowników. Zasadniczym zadaniem komisji jest ocena i podejmowanie decyzji w sprawie wprowadzania do zbiorów nowych nabytków, głównie przez preselekcję (w ramach cotygodniowych przeglądów) książek wpływających jako egzemplarze obowiązkowe, wskazywanie książek zagranicznych do zakupu, proponowanie zakupu książek na drugi czy kolejny egzemplarz. Członkowie tego zespołu decydują ponadto o lokalizacji materiałów bibliotecznych, umieszczaniu ich w kolekcjach i przesuwaniu między nimi, a także o prezencyjności poszczególnych druków. Poza tym odbywają się spotkania poświęcone selekcji czasopism wpływających z egzemplarza obowiązkowego. W przypadku ich gromadzenia również stosowana jest zasada kolegialnego podejmowania decyzji.

Z Oddziałem Gromadzenia ściśle współpracuje Zespół Bibliotekarzy Dziedzinowych [25]. Powstał on na bazie funkcjonującego już wcześniej w BU zespołu "fachreferentów”, konsultantów dziedzinowych przede wszystkim w zakresie kupna publikacji obcojęzycznych. W 2012 roku postanowiono zmodyfikować (rozszerzyć) formułę działania tychże specjalistów dziedzinowych - powołano nowy zespół i dopasowano jego

${ }^{15} \mathrm{O}$ organizacji pracy zespołów zob. A. Jazdon, Nowoczesne zarzadzanie w starych murach, w: Stare $i$ nowe w bibliotece. Wspótpraca czy konkurencja, red. M. Wrocławska, J. Jerzyk-Wojtecka, Łódź 2010, s. 89-100.

${ }^{16} \mathrm{O}$ zadaniach bibliotekarzy dziedzinowych szerzej zob. A. Jazdon, Unde venis?, w: Bibliotekarz dziedzinowy w bibliotekach akademickich, Torun 2001, s. 7-16. 
zadania do aktualnych potrzeb. W skład zespołu, podobnie jak poprzednio, weszli pracownicy o zróżnicowanym wykształceniu, aby decyzje merytoryczne $\mathrm{w}$ zakresie gromadzenia literatury z poszczególnych dziedzin były podejmowane przez osoby najlepiej przygotowane.

Założeniem funkcjonowania zespołu specjalistów dziedzinowych była w pierwszej kolejności współpraca ze środowiskiem uczelni oraz z bibliotekarzami bibliotek wydziałowych w zakresie gromadzenia i optymalnego wykorzystania zbiorów BU. Postulat ten okazał się jednak w przypadku większości wydziałów i ze względu na różne uwarunkowania dość trudny do wprowadzenia w życie. Natomiast z pełnym powodzeniem zespół współpracuje z kierownikiem i pracownikami Oddziału Gromadzenia, a także z Komisją Selekcji i Doboru w zakresie gromadzenia literatury z poszczególnych dziedzin. Część zadań obu zespołów pokrywa się (np. uczestnictwo we wspomnianych już selekcjach książek i czasopism), ale bibliotekarze dziedzinowi pełnią również funkcje głównych konsultantów, jeśli chodzi o zakupy literatury specjalistycznej w ramach usługi "Zaproponuj kupno książki", kupno publikacji obcojęzycznych, materiały wpływające z wymiany czy darów. Sprawują też nadzór merytoryczny nad portalami dziedzinowymi zamieszczonymi na stronie Biblioteki, na których prezentowana jest oferta literatury naukowej dostępnej na rynku wydawniczym, zakupione przez Bibliotekę nowości i posiadane przez nią źródła elektroniczne dotyczące poszczególnych dyscyplin.

W poprzek niejako obu zespołów działa wspomniany już zespół ds. selekcji bieżącej literatury pięknej. Został on utworzony - w dość nieformalny sposób - na początku 2012 roku z inicjatywy kierownika Oddziału Gromadzenia, a w tej chwili działa już oficjalnie pod auspicjami i jako część Komisji Selekcji i Doboru, przy czym jego funkcjonowanie wpisało się już w praktykę gromadzenia. Tworzą go wybrani bibliotekarze dziedzinowi (z zakresu filologii polskiej i klasycznej, anglistyki, filologii germańskiej i romańskiej) oraz inni pracownicy o wykształceniu filologicznym (poloniści i neofilolodzy), czyli z założenia osoby znające się na literaturze, a także miłośnicy, pasjonaci różnego typu literatury, którzy dzięki swym zainteresowaniom również mogą pochwalić się niemałą znajomością przedmiotu. Są to ponadto pracownicy różnych działów (od gromadzenia, przez opracowanie i kontrolę zasobu, po udostępnianie), co również sprzyja podejmowaniu trafnych decyzji. Efektem cyklicznych spotkań członków zespołu jest wypracowanie szczegółowych kryteriów doboru literatury pięknej, które w ogólnym zarysie zostały ujęte w zarządzeniu z 2013 roku [26], a na co dzień służą podejmowaniu optymalnych decyzji. Istotną przesłanką działania zespołu jest nie tylko preselekcja tomików poetyckich i powieści z egzemplarza obowiązkowego oraz darów, 
ale też aktywny udział w selekcji retrospektywnej przez wskazywanie autorów czy tytułów do wyłączenia ze zbiorów, o ile poziom utworu odbiega od przyjętych standardów, a statystyki wypożyczeń nie wskazują na zainteresowanie nim użytkowników.

Ostatnim rodzajem spotkań związanych z bieżącą pracą Oddziału Gromadzenia jest selekcja materiałów kierowanych do czytelni i poszczególnych pracowni Oddziału Zbiorów Specjalnych. Odbywa się ona średnio raz w miesiącu, z udziałem pracowników tego oddziału, reprezentujących poszczególne pracownie, a zarazem specjalistów w swoich dziedzinach.

Jak wynika z powyższego, konsekwentnie wspieramy kolegialne, zespołowe podejmowanie decyzji, oparte na uzgadnianiu, konsultowaniu, dyskutowaniu oraz wymianie uwag i sugestii. Wszystko to ma służyć jak najlepszej realizacji przyjętej polityki gromadzenia, a szerzej - zarządzania zasobami.

Wspominaliśmy wielokrotnie, że z realizacją polityki gromadzenia, w ramach której już na początku wykonujemy zadania związane z preselekcja ściśle wiążemy problemy selekcji retrospektywnej. W organizacji tych prac także przez lata dokonaliśmy poważnej zmiany. Od pierwotnego jej prowadzenia przez trzy osoby w ramach prac zleconych (prosta selekcja wieloegzemplarzowej literatury polityczno-społecznej w latach 80 . XX wieku), przez powierzenie tych zadań głównie pracownikom Oddziału Opracowania Rzeczowego Zbiorów [od 21] ze względu na klasyfikowanie przez każdego z nich wybranych, zgodnych z ich wykształceniem dziedzin piśmiennictwa, a więc i zakładaną doskonałą znajomość zasobu, aż do powołania w 2013 roku Zespołu ds. Selekcji Retrospektywnej w nowej formule [27, 28]. Jego skład w dużym stopniu opiera się na pracownikach wspomnianej komórki, ale uzupełniony jest też osobami z innych oddziałów, np. udostępniania, opracowania, kontroli zasobu. Zadaniem członków tego zespołu jest typowanie materiałów do selekcji z autopsji oraz na podstawie zapisów katalogowych. Informacje te trafiają do Oddziału Kontroli Zasobu, którego stworzenie w tej postaci, z tak przypisanymi mu zadaniami uważamy za duże osiągnięcie.

Oddział Kontroli Zasobu, w ramach standardowych działań (wydzielona sekcja), wykonuje typowe prace skontrowe. Jednakże i Sekcja Skontrum włącza się w prace pozostałych pracowników wykonujących zadania związane z porządkowaniem księgozbioru, wyszukiwaniem zagubień, wyjaśnianiem nieprawidłowości związanych na przykład z zapisami katalogowymi. Zajmują się oni systematyczną pracą nad scalaniem ciągów niepełnych, selekcjonowaniem materiałów wieloegzemplarzowych czy zniszczonych, przesuwaniem materiałów pomiędzy kolekcjami (np. wskazywaniem pozycji wąskospecjalistycznych do przekazania 
bibliotekom sieci). Zadaniem tego oddziału jest również z jednej strony wskazywanie tytułów „martwych”, z drugiej - sugerowanie zakupów kolejnych egzemplarzy w przypadku stwierdzania braku realizacji zamówień czytelniczych składanych na tytuły najbardziej "chodliwe”; wyznaczanie jako udostępnianych prezencyjnie tych książek, które są niedostępne na rynku, a więc niemożliwe do zdublowania w zasobie, a ze względu na ich częste wykorzystywanie winny być stale na miejscu. Zespół ten może także analizować częstotliwość wykorzystywania tytułów, np. zakupionych w ciągu ostatniego roku bądź z określonej dziedziny, przygotowując tym samym materiał do analiz dla kierownictwa Biblioteki. Stąd działania oddziału stanowią element stałej wewnętrznej kontroli zarządczej, pozwalają na szybkie uzyskanie informacji zwrotnej o prawidłowości tworzenia zasobu, a tym samym trafności zasad określanych $\mathrm{w}$ założeniach teoretycznych ${ }^{17}$. Tego typu analizy, przeprowadzane na podstawie zbieranych danych, mogą - na zlecenie kierownika Oddziału Gromadzenia - wykonywać pracownicy Oddziału Innowacji i Wdrożeń.

Kilka lat temu w BU powołany został Zespół ds. Narodowego Zasobu Bibliotecznego [27]. Obecnie, po zmianie przepisów, zbiory Biblioteki Uniwersyteckiej praktycznie nie należą już do tego zasobu. Jednakże został on przed laty fizycznie wyłączony. W jego skład, poza oczywiście zbiorami specjalnymi, weszły głównie druki poznańskie XIX i początku XX wieku. Dziś kolekcję tę nazywamy roboczo Regionalnym Zasobem Bibliotecznym. Istniejący zespół dba o to, aby dzięki zakupom ofertowym, aukcyjnym i antykwarycznym czy darom uzupełniać ewentualne braki, tak aby $\mathrm{w}$ pełni realizować zapisane $\mathrm{w}$ polityce gromadzenia zadanie dokumentowania dorobku wydawniczego regionu i powiększać posiadaną kolekcję. Warto dodać, że prace w tym zakresie wykonywane są w wewnętrznej bazie elektronicznej, rejestrującej te druki i ich lokalizację w czterech głównych bibliotekach miasta. Tym samym eliminuje się możliwość zdublowania zakupów. Zadaniem zespołu jest także współpraca z Zespołem ds. Wielkopolskiej Biblioteki Cyfrowej przez wskazywanie materiałów koniecznych czy wartych zdigitalizowania. I w tym wypadku współpraca z innymi bibliotekami miasta pozwala unikać powielania działań, w każdej z tych jednostek skasowane są na przykład roczniki tytułów prasy poznańskiej czy kolejnych pozycji wydawnictw seryjnych, dzięki czemu czytelnik w postaci zasobu elektronicznego uzyskuje

${ }^{17}$ O pracy Oddziału Kontroli Zasobu szerzej zob. H. Grabowska, Kontrola zasobu a marka Biblioteki Uniwersyteckiej w Poznaniu, w: Biblioteka jako marka. Materiały z VII Forum Młodych Bibliotekarzy w Łodzi 11-12 września 2012 r., red. J. Stawińska, Warszawa 2013 , s. 35-43. 
dostęp do pełnego ciągu, w rzeczywistości nieobecnego w całości w żadnej z miejscowych książnic. Te są z kolei zwolnione $\mathrm{z}$ bezowocnych często poszukiwań na rynku brakujących tomów bądź nabywania ich za zwykle dość wysokie ceny.

Wewnątrz Oddziału Gromadzenia i Uzupełniania Zbiorów odnotować można nieznaczne zmiany. Nie mamy tu na myśli powołania takich stanowisk pracy jak: ds. czasopism elektronicznych, e-booków, rozliczeń finansowych, których zorganizowanie było konieczne z powodu pojawiających się nowych zadań. Po wprowadzaniu rokrocznych ograniczeń w roku 2005 zlikwidowaliśmy ostatecznie dużą Sekcję Wymiany, ograniczając ją do jednego stanowiska pracy. Dla porównania, w latach poprzednich prowadzeniem wymiany zajmowało się nawet siedem osób. Na potrzeby bibliotek partnerskich kupowano i wysyłano około 10 000-14000 woluminów rocznie, otrzymując w zamian materiał niekoniecznie profilowy. Za bardziej sensowne uznaliśmy przeznaczanie wydawanych tak pieniędzy na celowy zakup książek. Praca wymagająca mniejszego wysiłku, likwidująca konieczność zagospodarowywania materiałów zbędnych, dająca być może mniejszy wpływ roczny, zapewniała nam jednak celowy, bardziej racjonalny wpływ nabytków.

Pierwotnie tytuły do zakupów wskazywali głównie bibliotekarze dziedzinowi, co oczywiście czynią do chwili obecnej. Aby zapewnić im, a także zapraszanym do współpracy w tym zakresie czytelnikom, możliwie najlepsze warunki do typowania literatury, kilkakrotnie w ciągu roku organizowaliśmy otwarte wystawy nowości zagranicznych, przygotowywane przez specjalistyczne firmy zewnętrzne. Organizacja wystaw książek i udział w nich umożliwiały wybór książek $\mathrm{z}$ autopsji, stwarzały możliwość dokładniejszej analizy treści publikacji i ograniczenia do minimum niewłaściwych wyborów. Pozwalały również zaangażować w typowanie książek do kupna szerokie grono osób z Biblioteki, w tym szczególnie bibliotekarzy dziedzinowych, oraz pracowników naukowych. Zakup książek bezpośrednio z wystawy gwarantował ponadto najniższe ceny.

Dążenie do celowości czynionych zakupów zaowocowało wprowadzeniem w drugiej połowie 2010 roku usługi „Zaproponuj kupno książki"18, umożliwiającej wszystkim zainteresowanym składanie konkretnych zamówień za pomocą formularza zamieszczonego na stronie internetowej BU. W początkowej wersji był to prosty formularz, niedający możliwości

${ }^{18}$ Zob. K. Adamiak, Badania satysfakcji użytkowników ustugi „Zaproponuj kupno książki" w Bibliotece Uniwersyteckiej w Poznaniu, w: Budowanie relacji z klientami biblioteki, red. J. Przybysz, P. Pioterek, M. Nowak, Poznań 2014, s. 73-91. 
identyfikacji (poza imieniem i nazwiskiem) osób zgłaszających zapotrzebowanie na książki. Dla celów statystycznych, ale też dla większego rozeznania zainteresowania usługa, w 2012 roku wprowadzono obowiązkowe do wypełnienia pola wskazujące na kategorię (status) osoby zamawiającej (student, doktorant, pracownik naukowy, inny) i przynależność do określonej jednostki (poszczególne wydziały bądź inne). Pozwoliło to ustalić najczęstszych odbiorców naszej usługi, a także kontrolować wydatki przeznaczane na potrzeby każdego wydziału. Warto podkreślić, że zgłaszane tytuły są nie tylko kupowane, ale również, o ile jest to możliwe, pozyskiwane dzięki wymianie zagranicznej bądź - w przypadku publikacji krajowych - przez egzemplarz obowiązkowy monitowany u wydawcy. Ponadto dokonujemy zakupów książek elektronicznych, o ile kupno publikacji w tej wersji jest korzystniejsze i bardziej zasadne albo nie występuje ona w wersji drukowanej. Natomiast w sytuacji niemożności dokonania zakupu kierujemy zamawiającego do Wypożyczalni Międzybibliotecznej.

Trzeba przyznać, że niemal od początku usługa „Zaproponuj kupno książki” cieszyła się sporym zainteresowaniem, do czego przyczyniło się nie tylko jej intensywne propagowanie, ale też przekazywanie sobie informacji o niej przez samych użytkowników. Owo rekomendowanie (tzw. marketing szeptany) jest bodaj najlepszą formą promocji. A dowiedzieliśmy się o tym fakcie, przeprowadzając kilkakrotnie badania ankietowe wśród użytkowników usługi, które z jednej strony miały na celu zbadanie stopnia ich satysfakcji, z drugiej - ewentualne zmodyfikowanie usługi zgodnie z sugestiami czytelników. Wyniki ankiety potwierdziły, że nasza usługa bardzo dobrze wpisała się w oczekiwania użytkowników i została przez nich pozytywnie przyjęta, ale wymagały od nas podjęcia działań ulepszających i usprawniających cały proces obsługi (szybkość sprowadzenia książki przez dostawców i dostarczenia jej do Biblioteki, szybkość opracowania i przygotowania książki do odbioru, a przede wszystkim ustawiczny kontakt mailowy z zamawiającym i informowanie go na bieżąco o postępach $\mathrm{w}$ realizacji zamówienia). Podjęte działania spotkały się z zadowoleniem użytkowników, co stwierdziliśmy $\mathrm{w}$ kolejnych badaniach. Usługa ta $\mathrm{w}$ zasadzie na trwałe wpisała się w praktykę gromadzenia, a my zawsze uwzględniamy ją w naszych planach finansowych. Jest to zresztą praktyczne realizowanie przyjętego założenia: $\mathrm{z}$ jednej strony racjonalne, sensowne, celowe zakupy (i wydawanie pieniędzy), z drugiej - maksymalne zaspokojenie potrzeb naszych odbiorców.

Wszystkie rozwiązania organizacyjne, ich wprowadzanie, modyfikowanie i ciągłe dostosowywanie do realiów i warunków, w jakich 
działamy, mają oczywiście na celu jak najwłaściwsze kształtowanie zasobu, zgodnie z przyjętą polityką gromadzenia. Do tego potrzeba jednak jeszcze kilku istotnych elementów: pracy zespołowej, elastyczności, otwartości na nowe i umiejętności dostosowywania się do zmieniających się uwarunkowań zewnętrznych.

\section{Podsumowanie}

Spoglądając z perspektywy lat na to, w jaki sposób podchodziliśmy do problematyki zarządzania zasobami, możemy z satysfakcją powiedzieć, że osiągnęliśmy zamierzony cel, co jednak nie oznacza, że praca w tym zakresie jest zakończona. Zakładamy bowiem, że znowu najpóźniej za dwa, trzy lata poddamy obowiązujące zapisy weryfikacji, zadając sobie po raz kolejny pytanie o ewentualną konieczność dokonania korekt. Zapewne także do poważnych zmian zmusi nas - o ile zostanie wprowadzona w zapowiadanej postaci - bardzo bolesna dla naszego Uniwersytetu, ze względu na historyczne uwarunkowania, decyzja o zmianie przepisów prawnych dotyczących obowiązkowych egzemplarzy bibliotecznych.

Już jednak od ponad 20 lat mamy sformułowany podstawowy zrąb zasad, zgodnie z którymi kształtujemy zasoby. Wydaje się, że w ich budowaniu zdołaliśmy uwzględnić wszystkie zasadnicze elementy, czyli: historię, tradycję kształtowania zasobu, zadania instytucji nadrzędnej, jaką jest Uniwersytet, zadania Biblioteki będącej instytucją mocno wplecioną w otoczenie społeczne, zmieniające się warunki funkcjonowania rynku wydawniczego i nowoczesnych technologii.

Zakładamy, że zaproszenie do podejmowania decyzji w zakresie zarządzania zasobami maksymalnie szerokiego kręgu pracowników Biblioteki, a także jej użytkowników, bazowanie na wynikach wewnętrznych kontroli i analiz pozwalają nam unikać błędów. Kształtowany przez nas zasób jest więc naukowy, o wysokich walorach informacyjnych, mimo swego ogromu stale aktualizowany. Jest nastawiony zwłaszcza na zaspokajanie bieżących potrzeb badawczych i naukowych pracowników nauki oraz dydaktycznych studentów czy doktorantów. Równocześnie jednak ważnym wyznacznikiem jego wartości są zbiory specjalne i szeroko rozumiane zbiory regionalne. Pierwsze to ściśle sprofilowane, bogate ilościowo zasoby, drugie, w perspektywie długich dziesięcioleci, stanowią najważniejsza, stale rozwijaną i uzupełnianą kolekcję.

Dążymy do tego, aby w zasobach wyróżniać te wąskie zakresy specjalizacji, dzięki którym Biblioteka wyróżnia się spośród innych tego typu instytucji w kraju czy na świecie: zbiory masońskie jako największa 
i najbardziej wartościowa kolekcja literatury masońskiej w Europie; zbiory ikonograficzne jako największy w mieście zasób dotyczący Poznania, niezbędny nie tylko naukowcom, ale i miłośnikom miasta, regionalistom; komiksy jako materiał dla bardzo zróżnicowanych grup odbiorców. Ostatnia specjalizacja wskazuje również na świadome ukierunkowanie zasobów na szersze, nie tylko związane ze światem nauki i badań, kategorie użytkowników, służy realizacji idei kulturowych i społecznych zawartych w hasłach: „Biblioteka miejscem spotkań”, „Biblioteka jako trzecie miejsce".

W kształtowaniu zbiorów i podejmowaniu na ich podstawie różnorodnych zadań staramy się, jak widać, uwzględniać zarówno historię i tradycję narastania zasobu, jak i potrzeby chwili bieżącej. Staramy się nie tylko wychodzić naprzeciw oczekiwaniom odbiorców, ale wyprzedzać je, czyniąc z Biblioteki miejsce interesujące, ważne i potrzebne.

\section{Bibliografia}

Adamiak K., Badania satysfakcji użytkowników ustugi "Zaproponuj kupno ksiażki” $w$ Bibliotece Uniwersyteckiej $w$ Poznaniu, w: Budowanie relacji z klientami biblioteki, red. J. Przybysz, P. Pioterek, M. Nowak, Poznań 2014, s. 73-91.

Cybulski R., Księgarstwo w społeczeństwie wspótczesnym, Warszawa 1978.

Głowacka M., Polonizacja ksiegozbioru Biblioteki Uniwersyteckiej w Poznaniu w latach 1919-1920, „Biblioteka” 2002, nr 6 (15), s. 87-96.

Grabowska H., Kontrola zasobu a marka Biblioteki Uniwersyteckiej w Poznaniu, w: Biblioteka jako marka. Materiały z VII Forum Młodych Bibliotekarzy w Łodzi 11-12 września 2012 r., red. J. Stawińska, Warszawa 2013, s. 35-43.

Jazdon A., Biblioteka Uniwersytecka w Poznaniu 1919-1994, „Kronika Miasta Poznania" 1994, nr 1/2, s. 330-344.

Jazdon A., Nowoczesne zarzadzanie w starych murach, w: Stare $i$ nowe w bibliotece. Wspótpraca czy konkurencja, red. M. Wrocławska, J. Jerzyk-Wojtecka, Łódź 2010, s. 89-100.

Jazdon A., O zarzadzaniu zbiorami, „Forum Książki” 1998, nr 2 (13), s. 8-9.

Jazdon A., Unde venis?, w: Bibliotekarz dziedzinowy w bibliotekach akademickich, Toruń 2001, s. 7-16.

Kubiak S., Biblioteka Uniwersytetu im. Adama Mickiewicza w Poznaniu 1919-1966, Poznań 1967.

Kubiak S., Rozwój bibliotekarstwa w Wielkopolsce po 1945 roku, w: Biblioteki Wielkopolski w służbie nauki i kultury (1945-1977), red. S. Kubiak, Poznań 1978, s. 139-161.

Stempniewicz M., Gromadzenie i uzupetnianie zbiorów 1919-1979, w: Dokumentacja działalności Biblioteki Głównej Uniwersytetu im. Adama Mickiewicza w Poznaniu 1919-1979, red. S. Kubiak, Poznań 1979, z. 1: Historia Biblioteki, s. 97-133. 
Wydra W., Biblioteka Uniwersytecka w Poznaniu. Zarys dziejów, w: Dokumentacja działalności Biblioteki Głównej Uniwersytetu im. Adama Mickiewicza w Poznaniu 1919-1979, red. S. Kubiak, Poznań 1979, z. 1: Historia Biblioteki, s. 15-31.

Założenie Kaiser-Wilhelm-Bibliothek w Poznaniu w latach 1898-1902 przedstawione przez Zarzad Kaiser-Wilhelm-Bibliothek, Poznań 1904, przeł. R. Piejko, „Biblioteka" 2012, nr 6 (15), s. 17-56.

\section{Załącznik}

Zarządzenia wewnętrzne Dyrektora Biblioteki Uniwersyteckiej związane $\mathrm{z}$ realizowaną polityką gromadzenia

[1] 1984, nr 1: Zasady obiegu wpływów bibliotecznych w Bibliotece Uniwersyteckiej w Poznaniu.

[2] 1989, nr 15: Zasady i profil gromadzenia zbiorów specjalnych w Bibliotece Uniwersyteckiej w Poznaniu oraz tryb ich opracowania.

[3] 1992, nr 11: Prowadzenie selekcji wpływów bieżących w Bibliotece Uniwersyteckiej w Poznaniu.

[4] 1992, nr 11(a): Zasady polityki gromadzenia zbiorów w systemie biblioteczno-informacyjnym UAM.

[5] 1992, nr 12: Tryb i zasady przekazywania do innych bibliotek miasta Poznania wpływów z eo uznanych w BU za zbędne.

[6] 1994, nr 5: Zasady i tryb prowadzenia selekcji księgozbioru głównego Biblioteki Uniwersyteckiej w Poznaniu.

[7] 1995, nr 4: W sprawie zaprzestania gromadzenia nieprofilowych materiałów bibliotecznych.

[8] 1997, nr 2: Uzupełnianie spisów czasopism i serii nie wprowadzanych do zbiorów Biblioteki Uniwersyteckiej.

[9] 1997, nr 3: Zasady podejmowania decyzji o wprowadzeniu do zbiorów Biblioteki Uniwersyteckiej wpływów o dyskusyjnej przydatności.

[10] 1997, nr 6: Zasady polityki gromadzenia zbiorów w systemie biblioteczno-informacyjnym UAM.

[11] 1997, nr 7: Zasady i profil gromadzenia zbiorów specjalnych w Bibliotece Uniwersyteckiej w Poznaniu.

[12] 1998, nr 1: Zasady i tryb prowadzenia selekcji retrospektywnej.

[13] 1999, nr 1: Ograniczenie gromadzenia gazet spoza województwa poznańskiego.

[14] 2001, nr 16: Zasady polityki gromadzenia zbiorów w systemie biblioteczno-informacyjnym UAM.

[15] 2001, nr 17: Organizacja gromadzenia zbiorów dla Biblioteki Collegium Europaeum.

[16] 2002, nr 4: Procedury gromadzenia, opracowania, przechowywania i udostępniania wydawnictw zwartych i ciągłych z załącznikami na CD-ROM i dyskietkach. 
[17] 2002, nr 5: Wykaz DŻS gromadzonych w Bibliotece Uniwersyteckiej w Poznaniu.

[18] 2003, nr 7: Zasady i profil gromadzenia zbiorów specjalnych w Bibliotece Uniwersyteckiej w Poznaniu.

[19] 2003, nr 10: Zasady i tryb prowadzenia selekcji retrospektywnej z księgozbioru głównego.

[20] 2004, nr 1: Wprowadzenie systemu rejestracji braków w zbiorach BU.

[21] 2005, nr 1: Polityka zarządzania zbiorami w systemie biblioteczno-informacyjnym UAM.

[22] 2006, nr 1: Wprowadzenie procedur gromadzenia, opracowania, przechowywania i udostępniania wydawnictw elektronicznych samoistnych oraz współwydanych.

[23] 2008, nr 4: Polityka zarządzania zasobami w systemie biblioteczno-informacyjnym UAM.

[24] 2008, nr 5: Tworzenie kolekcji komiksów.

[25] 2012, nr 2: Powołanie Zespołu bibliotekarzy dziedzinowych.

[26] 2013, nr 1: Polityka zarządzania zasobami w systemie biblioteczno-informacyjnym UAM.

[27] 2013, nr 2: Powołanie zespołów problemowych.

[28] 2013, nr 3: Zasady i tryb prowadzenia selekcji retrospektywnej z księgozbioru głównego.

\title{
MAŁGORZATA DĄBROWICZ, ARTUR JAZDON \\ The principles and execution of the resources management policy at Poznań University Library between 1992-2014
}

\begin{abstract}
Aвstract. The article investigates and discusses the changes in the management of resources at Poznań University Library that were implemented over the last two decades (between 1992-2014). Based on the analysis of the internal regulations and adjustments concerning the acquisition policy and surrounding issues, the authors present the evolutionary process of its development over the last twenty years that has led to its present shape. Against this particular background, the accompanying changes in the work organization, structure and the management of the Library are also discussed.
\end{abstract}

KEY WORDS: resource management, acquisition policy, collection acquisitions, acquisition sources, book selection, subject specialists. 